\title{
TAXONOMY OF IBERIAN ANISOLABIDIDAE (DERMAPTERA)
}

\author{
Mario García-París \\ Museo Nacional de Ciencias Naturales, MNCN-CSIC \\ c/José Gutiérrez Abascal, 2, 28006, Madrid. Spain. E-mail:mparis@mncn.csic.es
}

\begin{abstract}
An update on the taxonomy and geographic distribution of Iberian Anisolabididae (Dermaptera) is provided. Former catalogues reported in the Iberian Peninsula three genera of Anisolabididae: Aborolabis, Anisolabis, and Euborellia. A revision of 487 specimens of Iberian and North African Anisolabidoidea permit to exclude the genus Aborolabis from the Iberian fauna, the re-assignation of inland Euborellia annulipes Iberian records to Euborellia moesta, and the exclusion of Aborolabis angulifera from Northwestern Africa. Examination of type materials of Aborolabis mordax and Aborolabis cerrobarjai allows to propose the treatment of A. cerrobarjai as a junior synonym of $A$. mordax. The diagnostic characters of Euborellia hispanica are included within the local variability found in E. moesta. I propose that E. hispanica should be treated as a junior synonym of E. moesta.
\end{abstract}

Key words: earwigs, systematics, Mediterranean region, Spain, Morocco, NW Africa.

\section{INTRODUCTION}

The Iberian fauna of Dermaptera, including Anisolabididae Verhoeff, 1902, has been the subject of diverse revisionary (BoLívar 1876, 1897, LAPEIRA \& Pascual 1980, Herrera Mesa 1980, Bivar de Sousa 1997) and compilatory works (Herrera Mesa 1999). These revisions together with the monograph of the Fauna of France (Albouy \& Caussanel 1990) and the on-line information included in Fauna Europaea (HaAs 2010), rendered the image of Dermaptera as a well known group in continental western Europe. However, some Iberian Anisolabididae Verhoeff, 1902 described by Steinmann $(1978,1979,1981 a)$ remained ignored or included without further comments along successive catalogues (e. g. Steinmann 1989, Herrera Mesa 1999), and field surveys revealed that some published geographic data (Lapeira \& Pascual 1980, SteinmanN 1979) are incorrect or questionable.

The opportunity of revising some of the original specimens used by Steinmann $(1978,1979)$ along his descriptions of Iberian taxa at the Hungarian Natural History Museum (HNHM), and the availability for study of most of the specimens used by Bolívar (1897) and Lapeira \& Pascual (1980) for their revisonary work, at the Museo Nacional de Ciencias Naturales (MNCNCSIC) of Spain, allows the re-interpretation or re-identification of many of the taxonomically problematic specimens. Recent field work rendered new 
materials suitable for study, including specimens from near type localities of problematic species, facilitating further taxonomic decisions.

The objective of this work is to provide an update on the taxonomy and geographic distribution of Iberian Anisolabididae. As a result, I propose the synonymy of two taxa, and I reassign some previously mistaken geographic records.

\section{MATERIAL AND METHODS}

The basis for this study are the materials $(n=17)$ and type specimens $(n=10)$ of $A b$ orolabis held at Steinmann's collection in the Magyar Természettudományi Múzeum (Hungarian Natural History Museum, HNHM), plus a collection of 266 dry mounted Iberian specimens of Anisolabidoidea and 194 ethanol preserved specimens from the collections of the Museo Nacional de Ciencias Naturales (MNCN-CSIC) (Appendix 1).

Dry mounted specimens at the MNCN (acronym MNCN_Ent) have been gathered along the XIXth and XXth Centuries, and most of them are the product of the activity of well-known Spanish entomologists, including Ignacio Bolívar, Cándido Bolívar, José Arias, Ricardo Zariquiey, Manuel Martínez de la Escalera, Eugenio Morales Agacino, Francesc Español, Joaquín Mateu, Elvira Mingo and Vicenta Llorente. Specimens from the MNCN collection have been reported locally by previous authors, including some of the above mentioned. Special mention require Bolivar's $(1876,1897)$ catalogues, which served as the starting point for the study of Spanish Dermaptera, and the revision of LAPEIRA and PAsCUAL (1980). These authors used basically all the collection available at the MNCN at their time, but unfortunately, they did not provide any label to identify the material studied by them. The ethanol preserved materials, stored at $-18^{\circ} \mathrm{C}$ (acronym MNCN_tij) (Appendix 1), were collected along the period 2010-2014, mostly by the author and members of his research team (see acknowledgements).

Morphological studies were carried on using dry mounted specimens under stereomicroscope. Male genital structures were figured by Steinmann $(1979,1981 a)$.

\section{RESULTS AND DISCUSSION}

Recent catalogues (Steinmann 1989, Herrera Mesa 1999) reported the presence in the Iberian Peninsula of 7 species belonging to three genera of Anisolabididae: Aborolabis Srivastava, 1969, Anisolabis Fieber, 1853, and Euborellia Burr, 1909. However, data at hand do not support the presence of representatives of the genus Aborolabis in the Iberian Peninsula.

\section{Aborolabis}

The genus Aborolabis was integrated exclusively by southern Asian species (Srivastava 1969, 1972, 1976) until the addition by Steinmann (1978, $1979,1981 b, 1984$ ) of a set of Mediterranean and African species to the genus, adding up to a total of 13 species (Srivastava 1993). According to SteinmanN 
$(1979,1984,1989)$, the genus included five species in the Mediterranean Basin: Aborolabis mauritanica (Lucas, 1849), described from Algeria, Aborolabis mordax Steinmann, 1978, described from Tunisia, Aborolabis cerrobarjai Steinmann, 1979, described from Spain, A. rufocapitata Steinmann, 1984, described from Algeria, and Aborolabis angulifera (Dohrn, 1864) described from São Thomé, but recorded in Morocco by Steinmann $(1979,1989)$. Three of them, A. mauritanica, A. mordax, and A. cerrobarjai, have been reported in the Iberian Peninsula by STEINMANN $(1978,1979,1989)$.

I had the opportunity to revise part of the type material used by STEINMANN $(1978,1979,1984)$ for the original descriptions of A. mordax (Fig. 1a,b) and A. cerrobarjai (Fig. 2a,b), plus a series of specimens of northern African Aborolabis studied and identified by H. Steinmann, all located at the Hungarian Natural History Museum (HNHM).

The characters used in the descriptions and the key presented by STEINMANN (1979) to discriminate species, were focussed in coloration of the tibiae and femora, and also in the relative shape of male genital structures. STEINMANN (1979) used coloration of tibiae and the relative width of the triangular process of the internal margin of the male genitalia, to separate $A$. mordax and $A$. cerrobarjai, indicating that $A$. cerrobarjai presents yellow tibiae and the maximum width at the basis of the process, while A. mordax and A. mauritanica present dark tibiae and the maximum width at the middle of the process. Steinmann (1979) further separated A. mordax and A. mauritanica using coloration of the femora, black and yellow in A. mauritanica, all orange-yellow in A. mordax, and by relative shape of genital structures.

A direct examination of the type material of $A$. mordax and A. cerrobarjai (Figs 1,2) shows that Steinmann's original descriptions were precise and accurate. However, some of the materials of $A$. mordax and A. cerrobarjai studied by Steinmann $(1978,1979)$ correspond to immature male specimens. Immature and recently metamorphosed males in the family Anisolabididae show external secondary sexual characters and genital structures characteristically developed, but with a large variability (Jamet \& Caussanel 1995, Kamimura 2000, 2007, KAMIMURA \& IwASE 2010), probably a consequence of poor sclerotization. Coloration of tibiae is highly variable in northern African Aborolabis, from solid black to light cream and varies in immature and recently metamorphosed individuals. Tibiae colour changes in variable manner during the drying process after death. Legs of live nymphal specimens of A. mauritanica show a uniform cream light coloration which become darker after subsequent moults (Fig. 3).

The external and internal characters used by Steinmann $(1978,1979)$ to diagnose $A$. mordax and $A$. cerrobarjai correspond to intraspecific variability. Consequently, I propose that $A$. cerrobarjai is a junior synonym of $A$. mordax. 
According to Steinmann $(1978,1979)$, differentiation between A. mordax and $A$. mauritanica relies mostly on coloration of the femora: red and black in A. mauritanica (Fig. 4), totally yellow in A. mordax (Fig. 1). Both patterns are represented in the collection of adult specimens examined (see Appendix 1), but so far I have not observed intra-population variability for this character
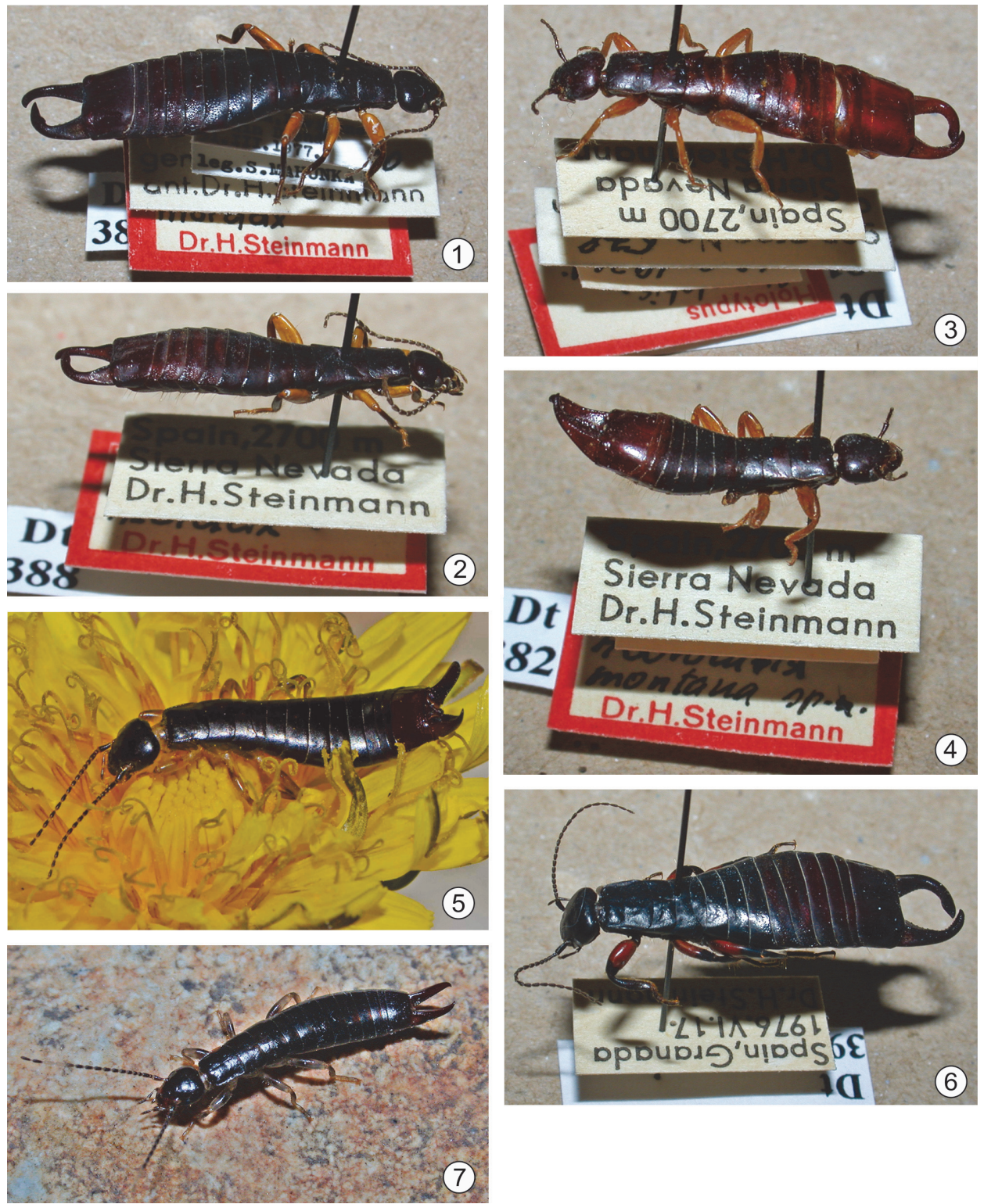
in adult specimens. Populations with specimens presenting the proximal two thirds of the femora red, are scattered over Eastern Morocco (Gâada de Debdou), central Algeria (Batna, Constantine), and Tunisia (El Kef), while populations with entire yellow femora are distributed over coastal Algeria (Kabylie, Fedja, Foret de Tagma) and Tunisia (Aïn Draham). It is likely that both morphs correspond to a single taxonomic unit, but I cannot confirm this point without the study of larger series.

The Iberian specimens of $A$. mordax (two paratypes) and A. cerrobarjai (the holotype and one paratype) available for study at the HNHM, are part of the same field series and bear identical labels, with the locality: "Spain, 2700 m Sierra Nevada" (Figs 1b, 2). Although, being part of the same field series could be used as a further argument to consider A. mordax and A. cerrobarjai part of a single taxon, I believe the geographic data attached to those specimens are incorrect.

Trying to obtain additional material of Aborolabis, I undertook three expeditions (July 2010, June 2011, June 2012) to Sierra Nevada (Granada, Spain), accompanied with experienced biologists from the national park (see acknowledgements). Our surveys included diurnal and nocturnal searches from 2500 to $3400 \mathrm{~m}$ along the western, southern and eastern slopes of the Sierra Nevada mountain range. We failed to find any specimen of Aborolabis, although we were able to find the other species of Dermaptera present at high elevations in the region (Eulithinus, Forficula).

The apparent absence of Aborolabis in Sierra Nevada was also stated by F. Pascual and A. Tinaut who made a fine scale prospection through all the Sierra Nevada National Park (unpubl. report) to determine the geographic distribution of Eulithinus analis (Rambur, 1838), a Sierran high elevation endemic earwig. They found Eulithinus in 127 squares of $1 \times 1 \mathrm{~km}$, but not a single specimen of Aborolabis was encountered during the surveys (A. Tinaut, pers. comm., May 2012). The revision of the collection of Iberian Dermaptera of the Museo Nacional de Ciencias Naturales (Madrid, Spain) did not provide any specimen of Aborolabis.

Figs 1-7. 1-2 = Aborolabis mordax Steinmann, 1978 (HNHM): 1 = holotype of $A$. mordax, male, "Tunisia. Environs of Ain Draham", 2 = paratype of $A$. cerrobarjai, a male labelled as collected in "Spain, 2700 m, Sierra Nevada". 3-4 = Aborolabis cerrobarjai Steinmann, 1979 (= A. mordax Steinmann, 1978) (HNHM), 4 = holotype of $A$. montana Steinmann, in litt. (= A. cerrobarjai Steinmann, 1981), male, "Spain, $2700 \mathrm{~m}$ Sierra Nevada", 4 = paratype of $A$. cerrobarjai, female, "Spain, $2700 \mathrm{~m}$ Sierra Nevada". 5 = Nymph of Aborolabis mauritanica (Lucas, 1846), from Gâada de Debdou (La Oriental, Morocco) (photo: by MG-P). Note the pale coloration of legs. Nymphs were observed while attended by an adult female, with typical red and black femora. 6 = Aborolabis mauritanica (Lucas, 1846), "Spain, Granada" (HNHM). 7 = Nymphal specimen of Euborellia moesta (Gené, 1839) from an urban garden of Madrid

(Spain) (photo: MG-P). Note the annulated femora and the pale antennal segments 
The only published data on the presence of Aborolabis in Iberia are those provided originally by STEINMANN $(1978,1979,1989)$ and reported again in subsequent works (see Herrera Mesa 1999, Pascual \& Barranco 2013). However, A. mauritanica and A. mordax are large, conspicuous, shiny black earwigs with orange-red or yellow legs (Figs 1-2, 4), which would not pass inadvertent to the hundreds of zoologists that have collected in the Sierra Nevada mountains, one of the better explored mountain ranges in Spain (RuANo et al. 2013).

To complicate matters, labels on the Sierra Nevada Aborolabis held at the HNHM, and reported by STEInMANN $(1978,1979)$, were written in the same type of paper, with the same writing, and apparently at the same time, as labels of Pseudochelidura montana Steinmann, 1981 (= Eulithinus montanus). Eulithinus montanus was described by STEINMANN (1981a) using specimens (type series examined) that only can be found at high elevations in Sierra Nevada, because the genus Eulithinus is endemic to this Spanish mountain chain. Steinmann must have been confused at some point, mixing the type series of $E$. montanus and the type series of $A$. cerrobarjai, since he labelled the types of $A$. cerrobarjai as: "Holotypus Aborolabis montana sp. n." and "Paratypus Aborolabis montana $s p . n$. ." It seems quite likely, that during the process of labelling the material, a part of the series of A. mordax from "Tunisia. Environs of Ain Draham 31.III.1977" got mixed with a series of Eulithinus from "Spain, $2700 \mathrm{~m}$ Sierra Nevada Dr. H. Steinmann // legit 18.6.1976 Dr. H. Steinmann", and subsequently described as $A$. cerrobarjai, or included as paratypes of $A$. mordax.

Using all the above evidence, I conclude that the reports of Aborolabis mauritanica and $A$. mordax (=A. cerrobarjai) in the Iberian Peninsula (all from Granada, Spain), are erroneous, and consequently the species should be eliminated from the Iberian catalogue of Dermaptera. I believe it is highly probable that the Aborolabis specimens studied by Steinmann were erroneously labelled, and that the specimens were likely collected in northwestern Africa.

Some species of Dermaptera are known to settle in non-native areas after accidental dispersal by human activities (Guillet et al. 2000, Nishikawa \& Kusui 2008, Pavón-Gozalo et al. 2011). Accidental introduction of A. mauritanica in southern Spain is possible, since maritime traffic is very active between the Spanish city of Almería and northern African coastal cities (CAstro Tovar \& FERRER 2007), but so far, there is no evidence of accidental transport of Aborolabis.

Incidentally, the Moroccan material studied and assigned by STEINMANN (1979) to A. angulifera (Berkane and Taforalt; see Appendix 1) corresponds to A. mauritanica. Consequently, A. angulifera should be removed from the Moroccan fauna. 


\section{Anisolabis}

Anisolabis is represented in the Iberian Peninsula and by Anisolabis maritima (Bonelli, 1832), an infrequent species in continental Portugal and Spain, widely distributed along the Atlantic and Mediterranean coasts (HARz \& Kaltenbach 1976, Albouy \& Caussanel 1990, Bivar de Sousa 1997, Herrera Mesa 1999).

Published records, as well as collection specimens (see Appendix 1) are scarce. The species, usually associated with seashore debris, is likely suffering the overdevelopment of the Mediterranean Spanish coast. The effect of tourism is specially strong along beaches, since most of the sand surface is being constantly "cleaned" by machines all over the tourist season, from spring to fall. Probably as a consequence of these practises, the only recent records of the species in the Mediterranean coast correspond to a population found under drying masses of Posidonia K. Koenig, located over the tide zone on sandy soil in Cabo de Palos (Murcia) (M. Calvo pers. com., July 2014). The species is today relatively common in northern African coastal areas (Ceuta: Playa Benítez: 8-VI-2011, J.L. Ruiz \& M.G.-París; Ceuta: San Amaro: 7-III-2012, J. L. Ruiz), Canary Islands (La Palma: Playa Nueva: 22-X-2010, M.G.-París), and Madeira (Porto da Cruz: 23-II-2013, N. Percino \& M.G.-París; Ponta Delgada: 1-III-2013 N. Percino \& M.G.-París).

\section{Euborellia}

The genus Euborellia is traditionally represented in the Iberian Peninsula by two widely distributed species, Euborellia annulipes (Lucas, 1847) and E. moesta (Gené, 1837) (Lapeira \& Pascual 1980, Herrera Mesa 1999). Steinmann (1981a), described a third Iberian species, Euborellia hispanica Steinmann, 1981, based on a single specimen from Olot (Province of Girona, Spain). The specimen, according to STEINMANN's (1981a) description, corresponds to a recently moulted immature specimen. I examined the morphological variability of a large series of adult and juvenile specimens of E. moesta from three different localities in Girona (located about $40 \mathrm{~km}$ from the type locality of E. hispanica), where it is a relatively common species (see records in Appendix 1).

The diagnostic characters indicated by STEINMANN (1981a) for E. hispanica are included within the local variability found in E. moesta from Girona, and, as indicated above, immature or recently metamorphosed males in the family Anisolabididae show external secondary sexual characters and genital structures highly variable.

I propose that E. hispanica and E. moesta represent the same taxon, and therefore E. hispanica should be treated as a junior synonym of E. moesta. Her- 
rera Mesa (1999) did not mention Steinmann's taxon, probably because the author considered Steinmann's E. hispanica a misapplication of Forficula hispanica Herrich-Schäffer, 1840 (= E. moesta), but Steinmann's (1981a) intention was clearly the description of a new species.

The geographic ranges of E. moesta and E. annulipes are not adequately analyzed in the Iberian territory. Along the examination of 360 specimens of Iberian Euborellia (see Appendix 1), I detected some misidentifications that allow us to question published reports. Those erroneous or doubtful records correspond to the presence of E. annulipes in central Spain. In fact, once revised the available specimens, the resulting geographic range of E. annulipes is mostly limited to coastal areas, or regions with a deep oceanic influence, while E. moesta is present over large areas in more continental situations.

The confusion might have arose from the fact that late nymphal instars of E. moesta (Fig. 5) present external morphological traits very similar to those retained by adult E. annulipes. Some of those traits, as for example, the presence of light legs annulated with dark brown rings, the presence of a whitish annuli on the distal portion of the antennae, or the absence of elytral pads, are often the only characters used for separation between E. moesta and E. annulipes. As a consequence, late nymphal instars of E. moesta are easily confused with adult $E$. annulipes. I believe that a large number, if not all, the reports of E. annulipes in central Spain correspond actually to E. moesta. I provide a list of confirmed localities in Appendix 1.

\section{Checklist of Iberian Anisolabididae}

According to the previous paragraphs, the Iberian fauna of Dermaptera includes four less species than previously considered: three species of Aborolabis, probably reported on the basis of erroneous labelling; and one species of Euborellia, a junior synonym of Euborellia moesta. The updated list of Iberian Anisolabididae remains as:

Anisolabididae Verhoeff, 1902

Anisolabidinae Verhoeff, 1902

Anisolabis Fieber, 1853

A. maritima (Bonelli, 1832)

Euborellia Burr, 1909

E. annulipes (Lucas, 1847)

E. moesta (Géné, 1837) ( = E. hispanica Steinmann, 1981 syn. nov.)

Species excluded of the Iberian Fauna of Anisolabididae: Aborolabis mauritanica (Lucas, 1849) and A. mordax Steinmann, 1978 (= A. cerrobarjai Steinmann, 1979 syn. nov.) 
Acknowledgements - I especially thank Nohemí Percino, Ernesto Recuero, Alex François, Jose Luis Ruiz, Gonzalo García and Pilar Pavón for help during field surveys to locate Aborolabis, and Jose Luis Ruiz, Marta Calvo, José Templado, Iñigo Martínez-Solano, David Buckley, Jorge Gutiérrez Rodríguez, David Osca and Iván Acevedo for providing specimens of Anisolabididae for study. Research in the Sierra Nevada National Park was possible thanks to the facilities provided by the national park and the enthusiasm of its staff; special thanks to José Miguel Barea Azcón for all his help in the high elevations. Alberto Tinaut (University of Granada) provided important additional information for this study. This work would have not been possible since the help of Judit Vörös and Dávid Murányi from the Hungarian Natural History Museum (Budapest), and Mercedes París curator of Entomology of the Museo Nacional de Ciencias Naturales (Madrid). I thank the projects CGL2014-53332-C5-1-P and CGL2015-66571-P (MINECO/FEDER) of the Spanish "Ministerio de Economía y Competitividad" for the facilities provided to complete this work.

\section{REFERENCES}

Albouy, V. \& Caussanel, C. (1990): Dermaptères ou Perce-oreilles. Faune de France, 75. Féderation Française des Sociétés de Sciences Naturelles, Paris, 248 pp.

Bivar De Sousa, A. (1997): Dermápteros (Insecta: Dermaptera) novos ou pouco conhecidos para Portugal continental. Boletim da Sociedade Portuguesa de Entomologia 6(17)(167) [1996]: 229-241.

Bolívar, I. (1876): Sinopsis de los ortópteros de España y Portugal. Anales de la Sociedad Española de Historia Natural 5: 79-130, 259-372.

Bolívar, I. (1897): Catálogo de los ortópteros de la Fauna Ibérica. Annaes de Sciencias Naturaes $4(3): 105-135$.

Castro Tovar, A. \& Ferrer, J. (2007): Morica favieri Lucas 1859 nueva para Europa y comentarios sobre el concepto de introgresión y sus implicaciones para la taxonomía del género Morica Solier 1836 (Coleoptera, Tenebrionidae, Pimeliinae). Boletín Sociedad Entomológica Aragonesa 40: 485-490.

Guillet, S., Josselin, N. \& VANCAssel, M. (2000): Multiple introductions of the Forficula auricularia species complex (Dermaptera: Forficulidae) in eastern North America. Canadian Entomologist 132(1): 49-57. http://dx.doi.org/10.4039/Ent13249-1

HaAs, F. (2010): Fauna Europaea: Dermaptera. In: Heller, K.-G. (ed.): Fauna Europaea: Orthopteroid orders. Fauna Europaea version 2.2, available at http://www.faunaeur. org [accessed 7 June 2010 as version 2.2 of 3 June 2009].

Harz, K. \& Kaltenbach, A. (1976): Die Orthopteren Europas III. W. Junk B.V., Publishers, The Hague, 434 pp. https://doi.org/10.1007/978-94-017-2513-2

Herrera Mesa, L. (1980): Nota sobre los dermápteros de Navarra. Graellsia 34[1978]: 195-203. Herrera Mesa, L. (1999): Catálogo de los dermápteros de España. Newbook Ed., Navarra, 203 pp. Jamet, P. \& Caussanel, C. (1995): Données biologiques, fonctionnement des appareils génitaux, comportements sexuels et maternels chez Euborellia annulipes (Lucas) (Dermaptère, Carcinophoridae). Bulletin de la Société entomologique de France 100(1): 37-58.

Kamimura, Y. (2000): Possible removal of rival sperm by the elongated genitalia of the earwig, Euborellia plebeja. Zoological Science 17(5): 667-672. https://doi.org/10.2108/ zsj.15.667 
Kamimura, Y. (2007): Possible atavisms of genitalia in two species of earwig (Dermaptera), Proreus simulans (Chelisochidae) and Euborellia plebeja (Anisolabididae). Arthropod Structure E Development 36(3): 361-368. https://doi.org/10.1016/j.asd.2007.03.003

KAmimura, Y. \& IwASE, R. (2010): Evolutionary genetics of genital size and lateral asymmetry in the earwig Euborellia plebeja (Dermaptera: Anisolabididae). Biological Journal of the Linnean Society 101(1): 103-112. https://doi.org/10.1111/j.1095-8312.2010.01491.x

Lapeira, A. \& Pascual, F. (1980): Estudio preliminar de los dermápteros de la fauna ibérica. Trabajos Monográficos del Departamento de Zoología de la Universidad de Granada, (n.s.) 3(4)[1977]: 53-99.

Legner, E. F. \& Olton, G. S. (1970): Worldwide survey and comparison of adult predator and scavenger insect populations associated with domestic animal manure where livestock is artificially congregated. Hilgardia 40(9): 225-266. https://doi.org/10.3733/ hilg.v40n09p225

Nishikawa, M. \& Kusui, Y. (2008): Earwigs (Dermaptera) collected in airplanes and ships called at ports in Japan. Tettigonia 9: 7-12.

Pascual, F. \& Barranco, P. (2013): Los Ortópteros y Dermápteros (Orthoptera y Dermaptera). Pp. 140-155. In: Ruano, F., Tierno de Figueroa, M. \& Tinaut, A. (2013): Los Insectos de Sierra Nevada. 200 años de historia. Vol. 1. Asociación Española de Entomología, Granada, 542 pp.

Pavón-Gozalo, P., Milá, B., Aleixandre, P., Calderón, J. A., Zaldívar-Riverón, A., Hernández-Montoya, J. \& García-París, M. (2011): Invasion of two distant areas of Mexico by Forficula auricularia (Dermaptera: Forficulidae). Florida Entomologist 94(4): 1088-1090. https://doi.org/10.1653/024.094.0457

Ruano, F., Tierno de Figueroa, M. \& Tinaut, A. (2013): Los Insectos de Sierra Nevada. 200 años de historia. Vol. 2. Asociación Española de Entomología, Granada, 528 pp.

Srivastava, G. K. (1969): On a new genus of Dermaptera from India. Entomologist's Record and Journal of Variation 81: 246-248.

Srivastava, G. K. (1972): Notes on a collection of Dermaptera from N.E.F.A. Records of the Zoological Survey of India 66(1-4): 129-142.

Srivastava, G. K. (1976): Notes on the genus Aborolabis Srivastava (Insecta: Dermaptera: Carcinophoridae), with description of a new species. Journal of the Zoological Society of India 26(Supplement 1974): 57-61.

Srivastava, G. K. (1993): Notes on the species of Aborolabis Sriastava [sic.]. Insecta: Dermaptera) from the Indian subcontinent. Records of the Zoological Survey of India 90[1992]: 23-35.

Steinmann, H. (1978): Dermaptera from Tunisia with a checklist of the North-African species. Folia entomologica hungarica (Series Nova) 31(1): 181-187.

Steinmann, H. (1979): A revision of the genus Aborolabis Srivastava, 1969 (Dermaptera: Carcinophoridae). Eos 53[1977]: 213-222.

Steinmann, H. (1981a): The Dermaptera of the Universitets Zoologiske Museum, Kovenhavn. Folia entomologica hungarica 42: 173-192.

Steinmann, H. (1981b): A study of the circumtropical Dermaptera material in the 'Instituut voor Taxonomische Zoologie', Amsterdam. Acta zoologica hungarica 27: 187-210.

Steinmann, H. (1984): The dermaptera material in the Museo Civico di Storia Naturale di Verona (Italy). Acta zoologica hungarica 30(1-2): 189-204.

Steinmann, H. (1989): Dermaptera. Catadermaptera II. Das Tierreich, 105. Walter de Gruyter, Berlin-New York, I-XIX + 504 pp.

Received October 18, 2015, accepted January 18, 2016, published March 3, 2017 


\section{APPENDIX 1}

Material examined. MNCN_ent = Museo Nacional de Ciencias Naturales (Entomology Collection) (Madrid). MNCN_tij = Museo Nacional de Ciencias Naturales (ethanol collection) (Madrid). HNHM = Hungarian Natural History Museum (Magyar Természettudományi Múzeum, Budapest).

\section{Anisolabis maritima (Bonelli, 1832)}

Spain: Andalucía: Cádiz: Algeciras: 1 specimen, C. Bolívar (Anisolabis Fieber maritima Géné [hand written by Bolívar]) (MNCN_Ent 81). Cataluña: Barcelona: Farola Llobregat: 9-III-1941, 1 specimen, F. Esp. [F. Español] (MNCN_Ent 109684); Garraf: 12-VII-1941, 1 specimen, J.M. (MNCN_Ent 109685); Garraf: 14-I-41, 3 specimens, E. Morales (MNCN_Ent 109686). Murcia: Murcia: Cabo de Palos, 6 m, 37ㅇ3'44.81”'N-042'11.25”'W: 20/21-VI-2014, 7 specimens, M. Calvo Revuelta \& J. Templado (MNCN_tij 14126-132); Cartagena: II-1925, 2 specimens, M. Escalera (MNCN_Ent 109682-83); Cartagena: 1 specimen, Sánchez Gómez (Anisolabis maritima (Bon.) det. E. Morales Agacino) (MNCN_Ent 109679); Cartagena: 2 specimens, Sánchez Gómez (MNCN_Ent 109680-81).

\section{Euborellia annulipes (Dohrn, 1864)}

Spain: Andalucía: Málaga: Playa de Benajarafe, 3 m, 36²42'57.3”N-04ำ11'42.0”W: 28-XII-2010, 3 specimens, M. García París \& G. García Martín (MNCN_tij 10126-128); Torre del Mar, 3 m, 36²43'54.2”N-0406'04.2”W: 28-XII-2010, 10 specimens, M. García París \& G. García Martín (MNCN_tij 10150-160). Cataluña: "Cataluña": 1894, 1 specimen, F. Traizet (MNCN_Ent 108650). Barcelona: Barcelona: 10-VIII-1905, 1 specimen, Arias (Anisolabis Fieber maritima Géné [hand written by Bolívar]) (MNCN_Ent 80); Barcelona, 20-VII-1940, 1 specimen, A. Pardo (MNCN_Ent 108638); Garraf: 14-II-1941, 11 specimens, E. Morales (MNCN_Ent 108645, MNCN_Ent 108647-49); Laguna Remola, Prat, Llobregat: 21-XI-1940, 1 specimen, F. Esp. [F. Español] (MNCN_Ent 108643); Montseny: 1 specimen, [Navás] (Anisolabis maritima Bon.) (MNCN_Ent 108651). Tarragona: Valls: 4-IX-1940, 2 specimens, F. Español (MNCN_Ent 108644, 46). Comunidad Valenciana: Valencia: Valencia: San Marcelino, Río Turia, 39²6'33.73”N-02330.41”W: 17-III-2012, 3 specimens, E. Recuero Gil, J. Gutiérrez Rodríguez (MNCN_tij 12617-619). Murcia: Murcia: Cabo de Palos, 6 m, 37운 $46^{\prime \prime} \mathrm{N}-0^{\circ} 42^{\prime} 14^{\prime \prime} \mathrm{W}$ : 20-IV-2014, 3 specimens, M. Calvo Revuelta (MNCN_tij 14055-057); Cartagena: 3 specimens, Sánchez Gómez (MNCN_Ent 108639, 41, 52); Totana: 2 specimens, Balaguer (MNCN_Ent 108640, 42). País Vasco: Guipúzcoa: Tolosa: VIII-1923, 1 specimen, Abajo (MNCN_Ent 108653).

\section{Euborellia moesta (Gené, 1839)}

Andorra: Sant Julià de Lòria: Bixessarri: Santuari de Canòlic, $1515 \mathrm{~m}, 42^{\circ} 28^{\prime} 31.5^{\prime \prime} \mathrm{N}$ 1²7'12.0”E: 20-VI-2013, 5 specimens, M. García París \& G. García Martín (MNCN_tij 13298-302).

Portugal: Vila Réal: 1 specimen, Dr. Martin (under Anisolabis annulipes identification label) (MNCN_Ent 109767) 
Spain: Andalucía: Almería: María: IV-1948, 2 specimens, Zarco (MNCN_Ent 10972930). Granada: Huéscar: 1 specimen, [Escalera] (MNCN_Ent 109727); [Pico de] La Sagra: 27-V-1950, 1 specimen, Mateu-Cobos. (MNCN_Ent 109733). Jaén: Arroyo de la Garganta, [Sierra de] Cazorla: 23-IV-1992, 1 specimen, C. Martín (MNCN_Ent 109754); Nava Foncuberta, S. [Sierra de] Cazorla: 27-VII-1956, 2 specimens, E. Mor. [E. Morales] (under Anisolabis annulipes identification label) (MNCN_Ent 109773, 109780); Jaén: Santiesteban [del Puerto], Sierra Sagra: 1 specimen, Juan Cabré (MNCN_Ent 109735). Sevilla: Sevilla, 1 specimen, Sanz (under Anisolabis annulipes identification label) (MNCN_Ent 109770). Aragón: Huesca: Almudévar: 3-V-1940, 1 specimen, E. Mor. [E. Morales Agacino] (MNCN_Ent 108659); S. [Sierra] de Guara: 1 specimen, Bolívar (MNCN_Ent 108688). Teruel: Albarracín: VII-1906, 5 specimens, Arias (under Anisolabis annulipes identification label) (MNCN_Ent 109756-760); Arcos de las Salinas, 1 specimen, Beltrán (MNCN_Ent 109741); Montalbán,

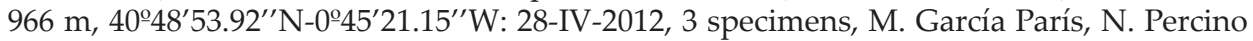
Daniel \& G. García Martín (MNCN_tij 12276-278); Teruel: 1-V-1935, 1 specimen, B. Muñoz (MNCN_Ent 109695); Teruel, 935 m: 20-III-1933, 1 specimen, B. Muñoz (MNCN_Ent 109701); Teruel, 935 m: 24-V-1933, 1 specimen, B. Muñoz (under Anisolabis annulipes identification label) (MNCN_Ent 109769); Teruel, Bezas, 935 m: X-1929, 1 specimen, B. Muñoz (under Anisolabis annulipes identification label) (MNCN_Ent 109766); Teruel, 935 m: III-30, 4 specimens, B. Muñoz (MNCN_Ent 109696-699); Teruel, 935 m: V-1929, 1 specimen, B. Muñoz (MNCN_Ent 109700); Teruel: 2 specimens, A. Sanz (MNCN_Ent 109694, 109702). Zaragoza: Bujaraloz, 326 m, 4129'42.8' N-009'03.1”W: 15-VI-2013, 1 specimen, M. García París \& G. García Martín (MNCN_tij 13265). Cataluña: "Cataluña": 1894, 1 specimen, F. Traizet (MNCN_Ent 109728). Barcelona: 7-IV-1941, 7 specimens, F. Esp. [F. Español] (MNCN_Ent 109745-46); Barcelona: 9-XI-1940, 1 specimen, J. Mateu (MNCN_Ent 108661); Calella: 1 specimen, Cuní (MNCN_Ent 109711); Farola Llobregat: 20-IV-1941, 2 specimens, F. Esp. [F. Español] (MNCN_Ent 109744); Farola Llobregat: 25-X-1940, 2 specimens, F. Esp. [F. Español] (MNCN_Ent 108663); Farola Llobregat: III-1941, 1 specimen, J. Mateu (MNCN Ent 109743); Farola Llobregat: IV-1941: 1 specimen, J. Mateu (MNCN_Ent 109742); Garraf: 7-IV-1941, 3 specimens, E. Morales (MNCN_Ent 108677); Montseny: 14-X-1941, 1 specimen, J. Mateu (MNCN_Ent 108670); Rabasada: 25-II-1941, 2 specimens, J. Mat. [J. Mateu]. (MNCN_Ent 108674); San Pedro Mártir: 2-III-1941, 7 specimens, J. Mateu (MNCN_Ent 108675-76); San Sadurní de Osormort: VII-1940, 2 specimens, F. Español. (MNCN_Ent 108664); Tagamanet: 26-I-1941, 2 specimens, J. Mat. [J. Mateu] (MNCN_Ent 108678); Vallirana: VI-1941: 1 specimen (under Anisolabis annulipes identification label) (MNCN_Ent 109779); Vallvidriera: 11-XI-1940, 1 specimen, J. Mat. [J. Mateu] (MNCN_Ent 108660); Vallvidriera: 29-X-1940, 3 specimens, J. Mat. [J. Mateu] (MNCN_Ent 108662). Girona: Arbucias: 1 specimen, Martorell (MNCN_Ent 109707); Cadaqués: IX-1941, 1 specimen, R. Zariquiey (MNCN_Ent 108656); Cabanes, 0 m, 42ํ17'59.9'N-0258'46.2”'E: 25-II-2011, 1 specimen, M. García París \& N. Percino Daniel (MNCN_tij 11011); Camprodón, 950 m: 25-IX-1940, 1 specimen, J. Mat. [J. Mateu] (MNCN_Ent 108672); Gerona: 12-X-1940, 2 specimens, E. Morales (MNCN_Ent 108665); Olot: 2 specimens, Cazurro (MNCN_Ent 109703-04); 2 km al SE de Cantallops, 148 m, 42²4’00.9”N-0257'04.6”'E: 25-II-2011, 11 specimens, M. García París

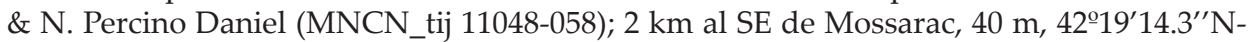
02058'42.4”E: 25-II-2011, 15 specimens, M. García París \& N. Percino Daniel (MNCN_tij 11012-026). Lleida: Sierra del Cadí: VIII-1906, 5 specimens, Arias (under Anisolabis annulipes identification label) (MNCN_Ent 109761-765). Tarragona: Montblanc, 355 m,

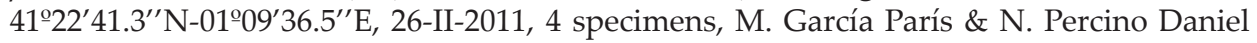
(MNCN_tij 11007-010); Valls: VIII-1946, 1 specimen, Español (under Anisolabis annulipes 
identification label) (MNCN_Ent 109771); Valls: 4-IX-1940, 2 specimens, F. Español (under Anisolabis annulipes identification label) (MNCN_Ent 109774-775). Castilla - La Mancha:

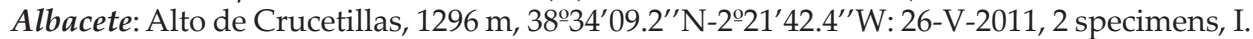
Martínez-Solano \& P. Pavón Gozalo (MNCN_tij 11724-725); Cañada de Haches, 1087 m,

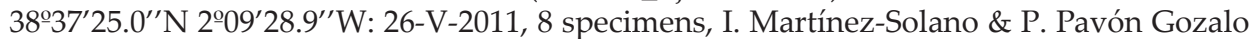
(MNCN_tij 11726-733); Cotillas: Arroyo de los Lavajos, $1054 \mathrm{~m}, 38^{\circ} 25^{\prime} 44.2^{\prime \prime} \mathrm{N}-2^{\circ} 28^{\prime} 57.6^{\prime \prime} \mathrm{W}$ : 26-V-2011, 1 specimen, I. Martínez-Solano \& P. Pavón Gozalo (MNCN_tij 11737); El Bonil-

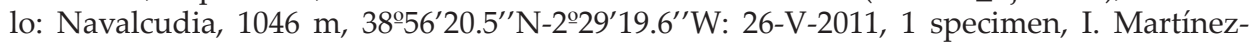
Solano \& P. Pavón Gozalo (MNCN_tij 11713); El Pardal: 4 specimens (MNCN_Ent 109723-

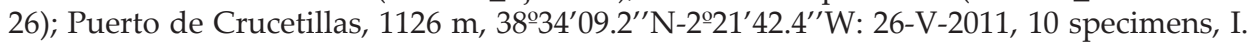
Martínez-Solano \& P. Pavón Gozalo (MNCN_tij 11714-723); 8 km al SE de Vianos, 1275 m, 38³5'26.7’’N-2²5'38.7’W: 27-III-2013, 1 specimen, M. García París \& N. Percino Daniel (MNCN_tij 13114). Cuenca: Cuenca: 3 specimens, F. Beltrán (MNCN_Ent 108701-03); Cuenca: V-1923, 10 specimens, J. Abajo (MNCN_Ent 108692-700, 734); Las Majadas, 1438 m, 40ำ16 15.7'N-2º2'08.1”W: 22-X-2012, 1 specimen, M. García París \& G. García Martín (MNCN_tij 12524), Uclés: 1 specimen, Pantel (MNCN_Ent 109705); Uclés: 1 specimen («placa anal anormal») (MNCN_Ent 109706); Uña, 4012'06.0”N-1ํ5'17.9”'W: 22-VI-2012, 2 specimens, E. Recuero Gil, I. Martínez-Solano, J. Gutiérrez Rodríguez (MNCN_tij 12569570); Villalba de la Sierra: 1978, 1 specimen, V. Llorente (MNCN_Ent 109750); 3 km al SE de Las Majadas, 1420 m, 4016'50.4”'N-159'38.5”'W: 30-IV-2011, 14 specimens, M. García París, N. Percino Daniel \& G. García Martín (MNCN_tij 11341-354); 5 km al SE de Las Maja-

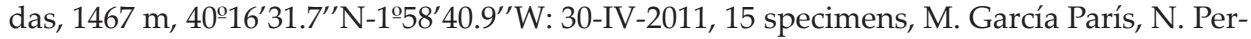
cino Daniel \& G. García Martín (MNCN_tij 11356-370). Guadalajara: Azañón, 1000 m: VIII-1956, 1 specimen, J. Abajo (MNCN_Ent 109736); Azañón: 10-V-1929, 2 specimens, [Escalera] (MNCN_Ent 108671); Guadalajara: IV, 1 specimen, Uhagón (MNCN_Ent 109692); Miralrío, 1023 m, 4053'36.7”N-2º56'22.1”W: 30-V-2002, 1 specimen, M. García París (MNCN_tij 11752); Trijueque: V-1934, 1 specimen, E. Mor. [E. Morales Agacino] (MNCN_Ent 108705); Trijueque, 996 m: 6-V-1934, 3 specimens, C. Bolívar (MNCN_Ent 109738-40). Toledo: Ocaña: IV-1948, 2 specimens, Zarco (MNCN_Ent 109731-32). Castilla y León: Burgos: Aranda [de Duero]: 3 specimens, Cogolludo (MNCN_Ent 109708-10). Comunidad Valenciana: Alicante: Alcoy: 11-IV-1936, 6 specimens, R. Verdú (MNCN_Ent 108667-69, 108673, 108679, 108689-90); Alcoy: 15-II-1936, 1 specimen, R. Verdú (MNCN_Ent 108666); Calpe, 3839'01.1”N-004'36.9”E: 9-IV-2011, 5 specimens, J. Gutiérrez Rodríguez

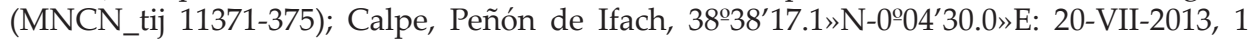
specimen, E. Recuero, J. Gutiérrez, D. Osca \& I. Acevedo (MNCN_tij 13355); Denia: 19-IV1934, 2 specimens, C. Bol. [C. Bolívar] (MNCN_Ent 109693, 109737); Orihuela: 25-VIII-1906, 1 specimen, Andreu (under Anisolabis annulipes identification label) (MNCN_Ent 109776); Orihuela: 5-IX-1906, 1 specimen, Andreu (under Anisolabis annulipes identification label)

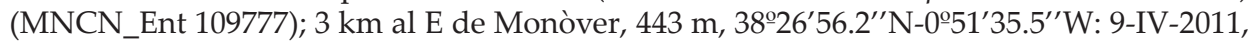
7 specimens, M. García París \& N. Percino Daniel (MNCN_tij 11221-227). Castelló: Atzen-

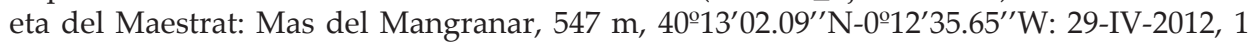
specimen, M. García París, N. Percino Daniel \& G. García Martín (MNCN_tij 12289); Castellfort, $924 \mathrm{~m}, 40^{\circ} 30^{\prime} 44.75^{\prime \prime} \mathrm{N}-0^{\circ} 08^{\prime} 44.08^{\prime \prime} \mathrm{W}$ : 28-IV-2012, 10 specimens, M. García París, N. Percino Daniel \& G. García Martín (MNCN_tij 12279-288). Valencia: Valencia: 1 specimen, Boscá (Brachylabis moesta G. Bosca!) (MNCN_Ent 109691): Valencia: 1 specimen, C. Bolívar (under Anisolabis annulipes identification label) (MNCN_Ent 109778). Extremadura: Bada-

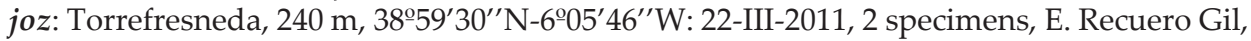
I. Martínez-Solano \& J. Gutiérrez Rodríguez (MNCN_tij 11154-155). Islas Baleares: Mal- 
lorca: Molinar levante: V/VI-1936, 1 specimen, Palau (under Anisolabis maritima identification label) (MNCN_Ent 109781); Mallorca: Palma: 1 specimen, Taboada (under Anisolabis annulipes identification label) (MNCN_Ent 109768); Observatorio de Costitx, $127 \mathrm{~m}$,

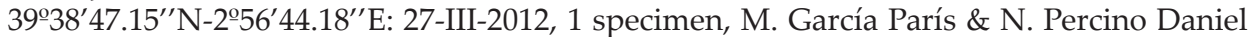

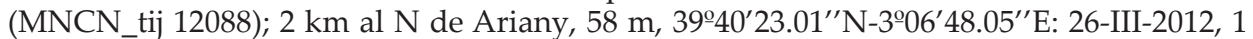
specimen, M. García París \& N. Percino Daniel (MNCN_tij 12086). Madrid: Madrid: Cadarso [Cadalso] de los Vidrios: 1 specimen, J. Alvarez (Euborellia ô moesta (Serv.) V. Llorente det. 1964) (MNCN_Ent 109747); Cadarso [Cadalso] de los Vidrios, 2 specimens, J. Alvarez (MNCN_Ent 109748-749); Canillas, Madrid: 24-IV-1937, 1 specimen, E. Morales

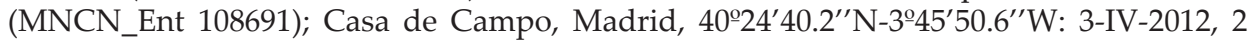
specimens, E. Recuero Gil (MNCN_tij 12153-154); Ciudad Universitaria, Madrid: 2-III1983, 2 specimens, M. García París (bajo piedras húmedas) (MNCN_Ent 109752-753); El Pardo, La Quinta: 21-V-1980, 1 specimen, E. Mingo (MNCN_Ent 109751); El Escorial: 3 specimens, Sanz (MNCN_Ent 108706, 109712713); Madrid: IV, 1 specimen, E. Morales (MNCN_Ent 109689); Madrid: 2 specimens, Arias (MNCN_Ent 108684-685); Madrid: 5 specimens, Bolívar (MNCN_Ent 108686-687, 109718-720); Madrid: 1 specimen, Cazurro (MNCN_Ent 109721); Madrid: 1 specimen, Dusmet (Anisolabis moesta + Gené) (MNCN_Ent 109722); Madrid: 2 specimens, J. Abajo (MNCN_Ent 109687-688); Madrid: 4 specimens, Sanz (MNCN_Ent 109714-717); Madrid: Jardines del Museo Nacional de Ciencias Naturales, $682 \mathrm{~m}, 40^{\circ} 26^{\prime} 29.74^{\prime \prime} \mathrm{N}$ - 341'21.26”'W: 16-X-2010, 1 specimen, M. García París (MNCN_tij 10080), 18-VII-2010, 6 specimens, M. García París (MNCN_tij 10002-007), 19VII-2010, 6 specimens, M. García París (MNCN_tij 10009-014), 7-X-2010, 2 specimens, M. García París (MNCN_tij 10017-018), 16-X-2010, 7 specimens, M. García París (MNCN_tij 10027-033); Montarco: IV-1932, 1 specimen, E. Morales (MNCN_Ent 109690); Nuevo Baztán: 5-VI-1892, 1 specimen, Escale [Escalera] (under Anisolabis annulipes identification label) (MNCN_Ent 109772); Tielmes: X-2002, 1 specimen, M. García París (MNCN_Ent 109755); Villaverde, 5 specimens, Arias (MNCN_Ent 108637, 108680-683); Villaverde, 1 specimen, Arias (Anisolabis Fieber moesta Serv. [hand written by Bolívar]) (MNCN_Ent 82). Murcia: Murcia: Murcia, Totana, 1938, 2 specimens, Balaguer (MNCN_Ent 108654-55). Navarra: Pamplona: Monteagudo: IV-1940, 4 specimens, E. Mor. [E. Morales Agacino]. (MNCN_Ent 108657-58).

\section{Aborolabis mauritanica (Lucas, 1846)}

Algeria: Akfadou: 1 specimen, 5-V-1979 (Gianasio [?]) (Dt 385) (HNHM); Batna - Talmet: 2 specimens (Dr. Martin) (MNCN_Ent); Batna: 1 specimen (Forf. gigantium) $\left(\mathrm{MNCN}_{-}\right.$ Ent); Batna: 2 specimens (Dr. Martin) (MNCN_Ent); Batna: 3 specimens (MNCN_Ent); Constantine: 5 specimens (MNCN_Ent).

Morocco: Berkane (M...d) [?]: 1 specimen, XI-1960 (Pardo Alcaide leg.) (Anisolabis mauritanica Lucas Pardo Alcaide det. 1960) [Aborolabis angulifera (Dohrn, 1864) det. Dr. H. Steinmann] (Dt 384) (HNHM); Taforalt, Maroc Nord: 1 specimen, XII-1960 (Pardo Alcaide leg.) (gen. prep. No. 28 ant. Dr. Steinmann) (Aborolabis angulifera (Dohrn, 1864) det. Dr. H. Steinmann) (Dt 383) (HNHM) [specimen reported by Steinmann, 1978].

SpaIN: Granada: 2 specimens, 17-VI-1976 (Dr. H. Steinmann) (Dt 393) (HNHM) [specimen reported by Steinmann, 1978] [mislabelled] 
Tunisia Ferme Shitta Djebel Eddyr ca. 7 km N from El Kef: 3 specimens, 28-III-1977 (No 17 leg. S. Mahunka) (Dt 401) (HNHM) [specimen reported by Steinmann, 1978]; Tunis: 2 specimens, XI-1941 (Dt 397) (HNHM); Tunis: 7 specimens, XI-1947 (Dt 398) (HNHM)

\section{Aborolabis mordax Steinmann, 1978}

Type material - Aborolabis montana (nomen nudum) = Aborolabis cerrobarjai Steinmann, 1979 = Aborolabis mordax Steinmann, 1978 (syn. n.)

Algeria: Fedja: 3 specimens (Dr. Martin) (MNCN_Ent); Fôret de Tagma: 2 specimens (329) (MNCN_Ent); Kabylie: 3 specimens (Dr. Martin) (MNCN_Ent).

Spain, 2700 m Sierra Nevada Dr. H. Steinmann [typed] // gen. prep. No. 578 det. Dr. Steinmann [number hand written] // 18.6.1976 [hand written] // Holotypus Aborolabis montana sp. $n$. Dr. H. Steinmann [name hand written, white label red edges] // Dt 381 [printed] [HNHM] [specimen reported by Steinmann, 1981 as holotypus of Aborolabis cerrobarjai] [male] [mislabelled] (Fig. 2a).

Spain, 2700 m Sierra Nevada Dr. H. Steinmann [typed] // 18.6.1976 [hand written] // Paratypus Aborolabis montana sp. $n$. Dr. H. Steinmann [name hand written, white label red edges] // Dt 382 [printed] [HNHM] [specimen reported by Steinmann, 1981 as paratypus of Aborolabis cerrobarjai] [female] [mislabelled] (Fig. 2b).

Tunisia. Environs of Ain Draham 31.III.1977 [typed] // No 38 leg. S. Mahunka [typed] // gen. prep. No. 570 det. Dr. Steinmann [number hand written] // Holotypus Aborolabis mordax Dr. H. Steinmann [name hand written, white label red edges] // Dt 386 [printed] [HNHM] [specimen reported by Steinmann, 1978] [male] (Fig. 1a).

Tunisia. Environs of Ain Draham 31.III.1977 [typed] // No 38 leg. S. Mahunka [typed] // Paratypus Aborolabis mordax Dr. H. Steinmann [name hand written, white label red edges] // Dt 387 [printed] [HNHM] [specimen reported by Steinmann, 1978] [male].

Tunisia. Environs of Ain Draham 31.III.1977 [typed] // No 38 leg. S. Mahunka [typed] // Paratypus Aborolabis mordax Dr. H. Steinmann [name hand written, white label red edges] [HNHM] [specimens reported by Steinmann, 1978] [3 female].

Spain, 2700 m Sierra Nevada Dr. H. Steinmann [typed] // Paratypus Aborolabis mordax Dr. H. Steinmann [name hand written, white label red edges] // Dt 388 [printed] [HNHM] [specimen reported by Steinmann, 1978] [male] [mislabelled] (Fig. 1b).

Spain, 2700 m Sierra Nevada Dr. H. Steinmann [typed] // Paratypus Aborolabis mordax Dr. H. Steinmann [name hand written, white label red edges] [HNHM] [specimen reported by Steinmann, 1978] [female] [mislabelled]. 


\title{
Natural History of the National Parks of Hungary
}

\author{
Editor-in-chief \\ I. MATSKÁSI
}

1. The Fauna of the Hortobágy National Park. Vol. I. Edited by S. Mahunka. - Akadémiai Kiadó, Budapest, 1981, 415 pp.

2. The Fauna of the Hortobágy National Park. Vol. II. Edited by S. Mahunka. - Akadémiai Kiadó, Budapest, 1983, 489 pp.

3. The Flora of the Hortobágy National Park. Edited by J. SzujkóLacza. - Akadémiai Kiadó, Budapest, 1982, 172 pp.

4. The Fauna of the Kiskunság National Park. Vol. I. Edited by S. Mahunka. - Akadémiai Kiadó, Budapest, 1986, 491 pp.

5. The Fauna of the Kiskunság National Park. Vol. II. Edited by S. Mahunka. - Akadémiai Kiadó, Budapest, 1987, 479 pp.

6. The Flora of the Kiskunság National Park. Vol. I. The flowering plants. Edited by J. Szujkó-Lacza and D. Kováts. - Hungarian Natural History Museum, Budapest, 1993, 469 pp.

7. The Fauna of the Bükk National Park. Vol. I. Edited by S. Mahunka and L. Zombori. - Hungarian Natural History Museum, Budapest, 1993, 456 pp.

8. The Fauna of the Bükk National Park. Vol. II. Edited by S. Mahunka, L. Zombori and L. Ádám. - Hungarian Natural History Museum, Budapest, 1996, 655 pp.

9. The Flora of the Kiskunság National Park. Vol. II. Cryptogams. Edited by L. Lőkös and M. Rajczy. - Hungarian Natural History Museum, Budapest, 1999, 466 pp.

10. The Fauna of the Aggtelek National Park. Vol. I. Edited by S. Mahunka and L. Zombori. - Hungarian Natural History Museum, Budapest, 1999, 371 pp.

11. The Fauna of the Aggtelek National Park. Vol. II. Edited by S. Mahunka and L. Zombori. - Hungarian Natural History Museum, Budapest, 1999, pp. 373-775.

12. The Fauna of the Fertő-Hanság National Park. Vol. I. Edited by S. Mahunka. - Hungarian Natural History Museum, Budapest, 2002, 404 pp.

13. The Fauna of the Fertő-Hanság National Park. Vol. II. Edited by S. Mahunka. - Hungarian Natural History Museum, Budapest, 2002, pp. 405-829. 